\title{
A deep protozoan maximum in the Gulf of Maine*
}

\author{
David W. Townsend \& Leon M. Cammen
}

Bigelow Laboratory for Ocean Sciences, McKown Point, West Boothbay Harbor, Maine 04575, USA

\begin{abstract}
We found a deep maximum in the abundance of larger protozoans ( $>35 \mu \mathrm{m}$ ) in the Gulf of Maine at depths from 55 to $100 \mathrm{~m}$, which was well below the euphotic zone, pycnocline, and the depths of peak biomass and production of both phytoplankton and bacteria. Our calculations of the energetics of these protozoan populations suggest that they are unable to obtain sufficient nutrition from local microbial production. We discuss the possibility that organic material, which settles out of the surface layer, might collect at a deep hydrographic anomaly and sustain the protozoans in the deep maximum.
\end{abstract}

\section{INTRODUCTION}

Microzooplankton, those organisms $<200 \mu \mathrm{m}$, form an important componen: of the plankton in many marine environments (Beers \& Stewart 1967. Takahaski \& Hoskins 1978, Heinbokel \& Beers 1979, Capriulo \& Carpenter 1983, Hernroth 1983, Revelente \& Gilmartin 1983). Protozoans usually dominate the microzooplankton numerically and are in general phagotrophic, feeding on a wide variety of particulates (Parsons et al. 1967, Capriulo 1982). Typically, protozoan distributions are similar to those of the phytoplankton with greatest numbers at relatively shallow depths and a marked decrease in abundance below the depth of the euphotic zone (Beers \& Stewart 1969, Capriulo \& Carpenter 1983). Recently, it has been suggested that microzooplankton may play an important role in a trophic link recycling carbon in the planktonic food web (Williams 1981, Azam et al. 1983). From 5 to $50 \%$ of the carbon fixed by phytoplankton may be released as dissolved organic matter (DOM) and subsequently utilized by bacteria (Larsson \& Hagström 1979, 1982, Bell 1980, 1983, Bell \& Sakshaug 1980, Fuhrman et al. 1980, Rheinheimer 1981, Wolter 1982, Azam et al. 1983, Chrost \& Faust 1983, Jensen 1983). These bacteria are consumed by microheterotrophic flagellates (Haas \& Webb 1979, Fenchel 1982) which in turn are consumed by microzooplankton (Azam et al. 1983, Linley et al. 1983). Since the microflagellates and microzooplankton span the size range of the phytoplankton, the DOM lost by the phytoplank-

\footnotetext{
- Bigelow Laboratory Contribution Number 84017
}

ton is returned to the planktonic food web via this 'microbial loop' (Azam et al. 1983). We report here the existence of a deep maximum in the larger protozoans $(>35 \mu \mathrm{m})$ in the Gulf of Maine which occurs in association with a deep particulate layer but does not conform to the above scenario. This protozoan maximum occurs well below the euphotic zone, pycnocline, and the peaks in biomass and production of both phytoplankton and bacteria. Our results suggest that in this situation the bacteria-microheterotroph link is of only minor importance, and that the microzooplankton in the deep layer are either migrating diurnally into shallower, relatively food-rich waters, or they are consuming directly recently-settled biogenic particles that have become concentrated at a deep hydrographic anomaly.

\section{MATERIALS AND METHODS}

We have measured the vertical distributions of microzooplankton concurrently with those of other biological and physical parameters on two cruises (Sep 1982 and Aug 1983) at stations in the deeper waters of the Gulf of Maine (Fig. 1). On the first cruise, we carried out a survey of the vertical distributions of microzooplankton, chlorophyll, temperature, salinity and current speed and direction at 4 widely-dispersed stations in the Gulf of Maine. On the second cruise we concentrated our efforts on a single station in Wilkinson Basin and measured the vertical distributions of particulates, bacterial abundance and production, and primary production in addition to the same measurements we made on the first cruise. 


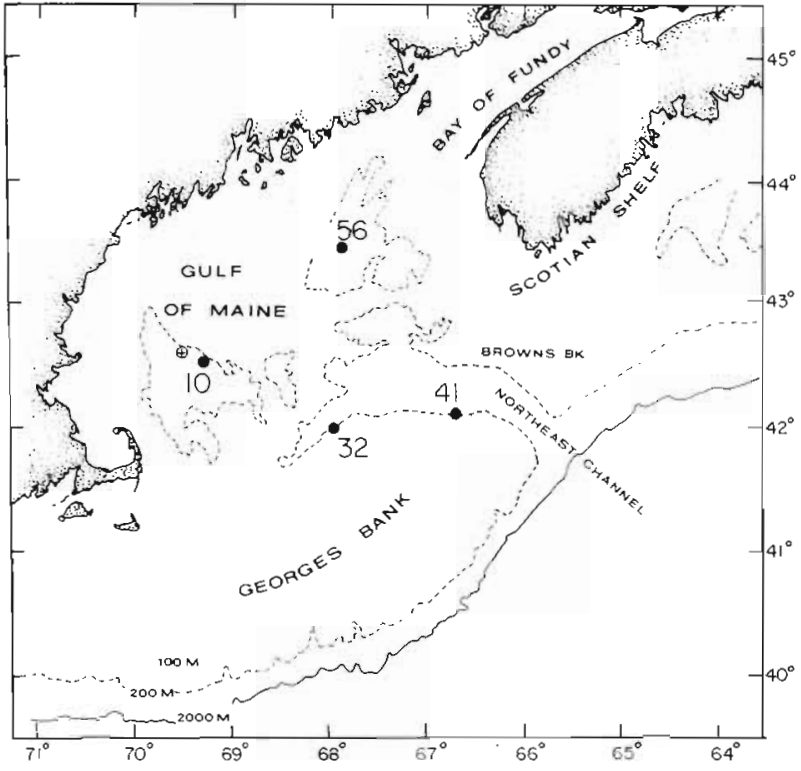

Fig. 1. Map of the Gulf of Maine showing depth contours and station locations referred to in the text. stations sampled 8 to 15 Sep 1982; $\oplus$ station sampled 7 to 9 Aug 1983
Samples were taken both by 51 Niskin bottles and with a vertical pumping system operating along with a Neil Brown accoustic doppler current meter with CTD capabilities. The pumping system was used to collect the zooplankton. This included a Flygt Model B205 submersible pump, $125 \mathrm{~m}$ of flexible $5 \mathrm{~cm}$ diameter hose and an on-deck distribution system which supplied a constant flow (ca $140 \mathrm{l} \mathrm{min}^{-1}$ ) to $35 \mu \mathrm{m}$ mesh plankton nets suspended in an $800 \mathrm{I}$ tub (King 1984, Townsend et al. 1984).

Microzooplankton samples were vertically integrated over several discrete depth strata while the pump-hose intake nozzle and current meter/CTD were raised from the deepest point to the surface at a rate of $1 \mathrm{~m}$ every $30 \mathrm{~s}$. The samples were preserved in $5 \%$ buffered formalin, concentrated in Imhoff cones, a subsample diluted to about 10 times the settled volume, and enumerated using a Palmer cell and $200 \times$ magnification. Counts were repeated when there were less than 100 organisms per counting cell.

Primary production was measured on the second cruise using the ${ }^{14} \mathrm{C}$-bicarbonate method in situ (Strickland \& Parsons 1972). Water samples were taken
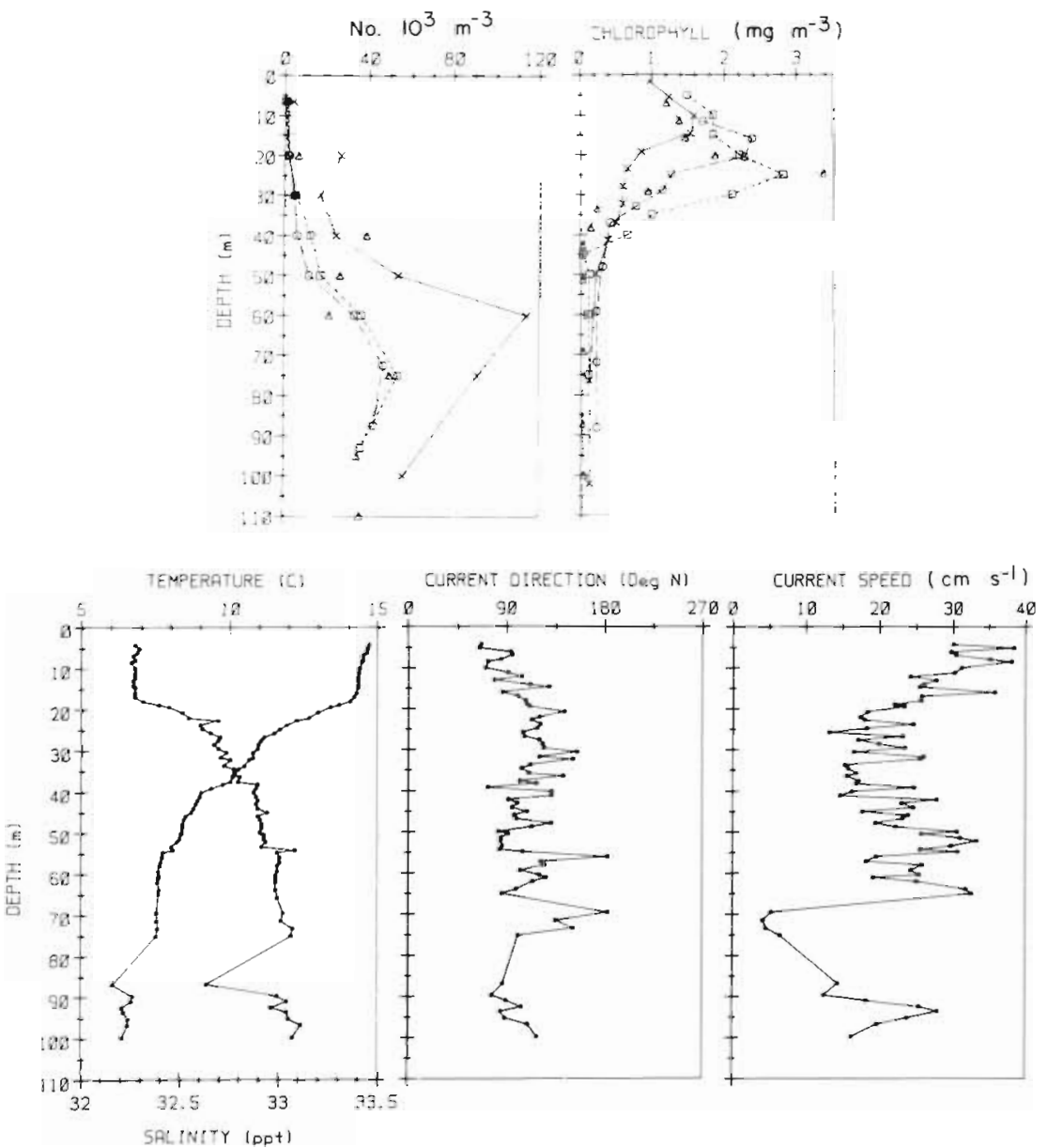

Fig. 2. Vertical distributions of total numbers of protozoans and total phytoplankton chlorophyll for all stations, sampled with the pumping system, and vertical profiles of temperature and salinity, current direction and speed, sampled with the Neil Brown accoustic doppler current meter and CTD for the Wilkinson Basin station (Sta. 10), for 8 to 15 Sep 1982. Current meter data are relative and have not been corrected for the ship's drift. Protozoan abundances are expressed as thousands of individuals $\mathrm{m}^{-3}$, total chlorophyll as $\mathrm{mg} \mathrm{m}^{-3}$. Points plotted for protozoans represent the midpoint of the integrated depths for pump samples. Chlorophyll profiles represent discrete depths sampled with the pump. Four stations in the Gulf of Maine were sampled: $\triangle$ Station $56\left(42^{\circ} 17^{\prime} \mathrm{N}, 67^{\circ} 47^{\prime} \mathrm{W}\right)$, $\square$ Station $10\left(42^{\circ} 36^{\prime} \mathrm{N}, 69^{\circ} 25^{\prime} \mathrm{W}\right)$, O Station $32\left(42^{\circ} 05^{\prime} \mathrm{N}, 67^{\circ} 52^{\prime} \mathrm{W}\right), \mathrm{X}$ Station 41 $\left(42^{\circ} 15^{\prime} \mathrm{N}, 66^{\circ} 45^{\prime} \mathrm{W}\right)$. Stations 10,56 and 32 were sampled between 0800 and 1600 h local time, Station 41 during darkness at $0400 \mathrm{~h}$ 
at $2,8,15,20,25$, and $40 \mathrm{~m}$ and incubated for $4 \mathrm{~h}$ with added ${ }^{14} \mathrm{C}$ in 2 light and 1 dark $150 \mathrm{ml}$ bottles at each depth. The contents of each bottle were then collected on $0.2 \mu \mathrm{m}$ Nuclepore filters which were placed in Aquasol-2 and counted on a scintillation counter; the dark values were subtracted from the light. Total chlorophyll analyses were carried out in duplicate following Yentsch \& Menzel (1963).

Bacterial abundance and production were determined for all depths (2 to $80 \mathrm{~m}$ ) on the second cruise. Bacterial abundance was measured for duplicate $10 \mathrm{ml}$ samples from each depth using DAPI stain and epifluorescence (Porter \& Feig 1980); attached cells were separated from free-living cells by using both 0.2 and 3 $\mu \mathrm{m}$ Nuclepore filters. Bacterial production was measured using ${ }^{3} \mathrm{H}$-thymidine incorporation (Fuhrman \& Azam 1982). The incubations were carried out for 60 to 70 min in dark, temperature-controlled water baths.
The concentration of particles $>8 \mu \mathrm{m}$ was determined on the second cruise using a Spectrex laser particle counter. Following several gentle inversions of the 51 Niskin bottles, $500 \mathrm{ml}$ of water was removed and counted either 2 or 3 times. In situ profiles of relative particulate concentrations were also measured with a $25 \mathrm{~cm}$ path length transmissometer.

\section{RESULTS}

On the first cruise we observed a maximum in the abundance of $>35 \mu \mathrm{m}$ protozoans between 55 and $85 \mathrm{~m}$, which was deeper than the maxima for post naupliar and naupliar copepods, chlorophyll and the thermocline/pycnocline as was reported earlier (Townsend et al. 1984) (Fig. 2). The most abundant protozoans were the heliozoan Sticholonchesp. and various tintin-
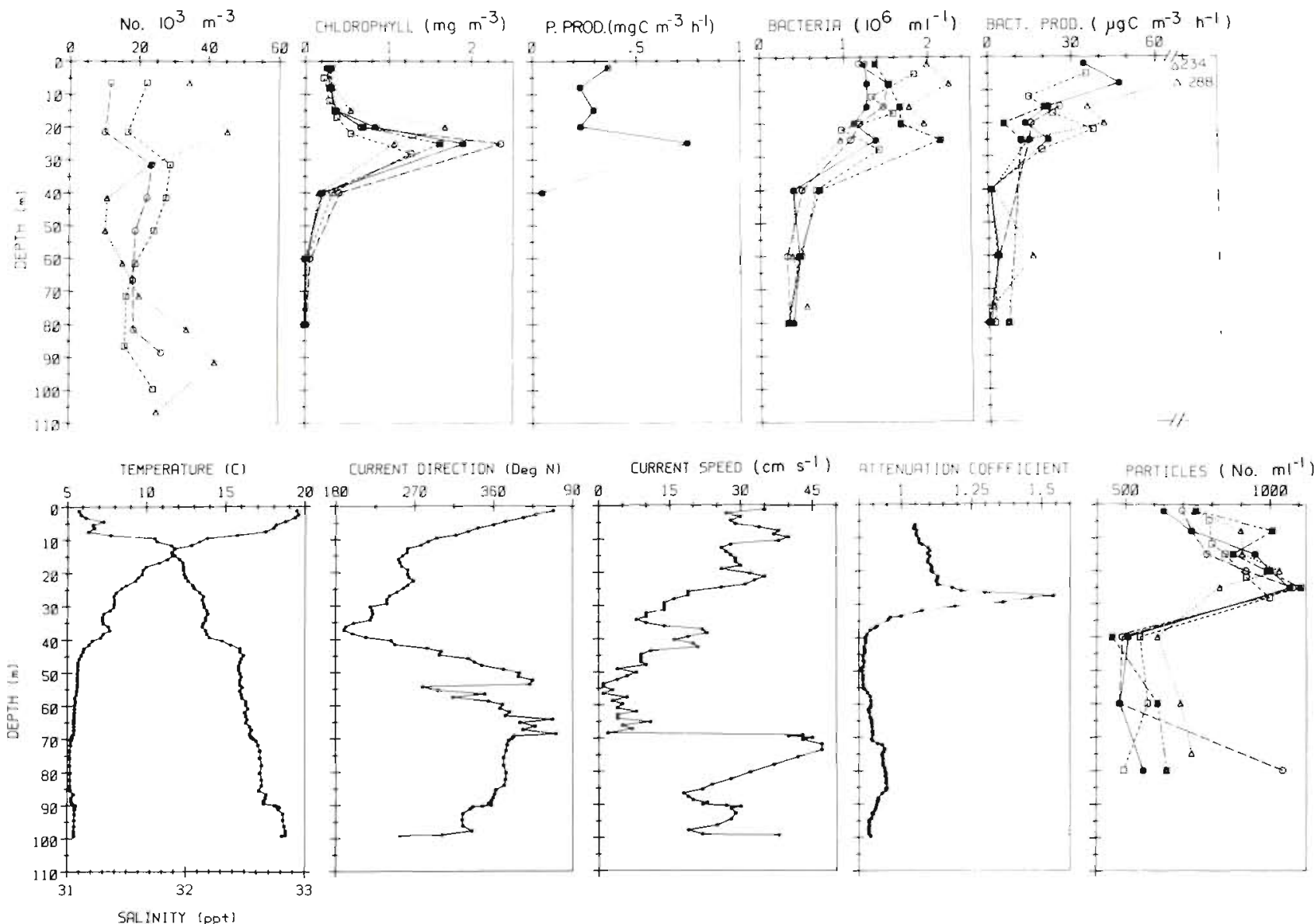

Fig. 3. Biological and physical measurements during the Aug 1983 cruise. All samples were collected near Station $10\left(42^{\circ} 53^{\prime} \mathrm{N}\right.$, $69^{\circ} 42^{\prime} \mathrm{W}$ ) from 7 to 9 Aug. Vertical distributions of protozoans for 3 pump profiles given as thousands of individuals $\mathrm{m}^{-3}$; total chlorophyll as $\mathrm{mg} \mathrm{m}^{-3}$; primary production based on in situ ${ }^{14} \mathrm{C}$-bicarbonate uptake, as $\mathrm{mg} \mathrm{C}^{-3} \mathrm{~h}^{-1}$; bacterial abundances, as millions $\mathrm{ml}^{-1}$; bacterial production based on the incorporation of ${ }^{3} \mathrm{H}$-thymidine into DNA, as $\mu g \mathrm{C} \mathrm{m}^{-3} \mathrm{~h}^{-1}$; numbers of particles $(>8 \mu \mathrm{m})$ counted with the Spectrex laser particle counter, as numbers $\mathrm{ml}^{-1}$; physical data as in Fig. 2 . With the exception of the transmissometer, for which the beam attenuation coefficient is given, all measurements are based on casts made with $5 \mathrm{l}$ Niskin bottles. $\triangle$ Daytime cast No. 1; $\square$ night-time cast No. 1; O night-time cast No. 2; $\square$ daytime cast No. 2 ; $\bullet$ daytime cast No. 3 . All daytime samples were collected between 0730 and $1200 \mathrm{~h}$ local time; night-time samples, between 2130 and $2400 \mathrm{~h}$ 
nids, principally the genus Tintinnopsis. They appeared to be associated with a deep current shear and the weak pycnocline at the base of the remnants of an intermediate water mass of low temperature and salinity (Fig. 2), which is formed during winter overturn in the Gulf of Maine and which rests on top of a warm, high salinity bottom layer originating from slope water (Hopkins \& Garfield 1979).

The vertical distributions of protozoans on the second cruise were generally bimodal, with a deep peak between 75 and $100 \mathrm{~m}$, similar to that seen on the first cruise, and a second, shallower peak between 20 and $40 \mathrm{~m}$ (Fig. 3). Loricate tintinnids were the dominant group at both depths. The vertical distributions of $>8 \mu \mathrm{m}$ particles were also bimodal, with a peak in the subsurface chlorophyll maximum (SCM) layer and a second smaller increase at 75 to $80 \mathrm{~m}$. This distribution was also evident in the transmissometer profile. The deep protozoan maximum and, as on the first cruise, the deep particulate maximum were associated with a deep current shear and the cooler, less saline intermediate water mass; but in contrast to the first cruise, there was only a weak pycnocline at these depths (Fig. 3). Maximum phytoplankton production occurred in the SCM and maximum bacterial production was in the warmer, near-surface waters. Thus for both bacteria and phytoplankton, the depth of maximum production coincided with the depth of maximum biomass. Phytoplankton and bacterial biomass and production at the depths of the deep protozoan maxima were extremely low despite the increased levels of particulate material.

\section{DISCUSSION}

Deep particulate and microbial (bacterial) biomass maxima have been reported from various coastal and oceanic regions( Sorokin 1964, Holm-Hansen \& Booth 1966, Pomeroy \& Johannes 1968, Devol et al. 1976, Karl $\&$ Holm-Hansen 1978, Garfield et al. 1983). The ultimate source of nutrition for the bacteria at these depths is probably derived from organic particles which have either settled out of the surface waters or have been advected into the region. These particles tend to concentrate dissolved organic and inorganic nutrients and serve as sites of increased microbial activity (Pomeroy \& Johannes 1968, Jannasch \& Pritchard 1972, Marshall 1979, Shanks \& Trent 1979, Paerl \& Merkel 1982, Pedrós-Alió \& Brock 1983). In coastal waters the relative contributions of free-living bacteria and those attached to particles vary. Hodson et al. (1981) reported that in shelf waters of the southeastern US the relative biomass of small $(<0.5 \mu \mathrm{m})$ free-living and larger attached ( 1 to $2 \mu \mathrm{m}$ ) bacteria were approximately equal while Pomeroy et al. (1983) reported that attached bacteria were 2 orders of magnitude less abundant. Cammen \& Walker (1982) also found the relative contributions to vary in the Bay of Fundy. Our results from August 1983 showed that about $90 \%$ of the bacteria at our Gulf of Maine station were free-living, even in the deep particulate maximum, and that the total numbers and productivity of bacteria in the deep protozoan and particulate maximum were very low.

Our observations of the near-surface waters during the August cruise appear to fit well within a conventional pelagic food web since we saw relatively high rates of production of phytoplankton and bacteria along with high abundances of $>35 \mu \mathrm{m}$ protozoans. The deep maximum in protozoans is problematic, however, since there was no concomitant increase in either phytoplankton or bacterial production as might be expected (Caron et al. 1982). Some simple calculations emphasize the problem. Using a mean ingestion rate for tintinnids (which accounted for most of the protozoans on our second cruise) of $0.026 \mu \mathrm{g} \mathrm{C}$ individual $^{-1}$ $\mathrm{d}^{-1}$ (Capriulo 1982) along with our measures of bacterial and phytoplankton production at the depths of the SCM and the deep protozoan maximum, and our estimated densities of protozoans (Fig. 3), we calculate that the carbon requirement of the shallow protozoan layer (ca. $1.2 \mathrm{mg} \mathrm{C} \mathrm{m}^{-3} \mathrm{~d}^{-1}$ ) is easily met by the sum of phytoplankton $\left(9.0 \mathrm{mg} \mathrm{C} \mathrm{m}{ }^{-3} \mathrm{~d}^{-1}\right)$ and bacterial $(0.3$ to $0.5 \mathrm{mg} \mathrm{C} \mathrm{m}^{-3} \mathrm{~d}^{-1}$ ) production rates. However, in the deep protozoan layer the carbon requirement $(1.1 \mathrm{mg}$ $\left.\mathrm{C} \mathrm{m}^{-3} \mathrm{~d}^{-1}\right)$ is not met by local production of bacteria $\left(<0.1\right.$ to $\left.0.2 \mathrm{mg} \mathrm{C} \mathrm{m}^{-3} \mathrm{~d}^{-1}\right)$. Although we did not measure phytoplankton production at this depth $(75$ m), production was only $0.6 \mathrm{mg} \mathrm{C} \mathrm{m} \mathrm{m}^{-3} \mathrm{~d}^{-1}$ at $40 \mathrm{~m}$ where chlorophyll was about 20 times more abundant; since the $1 \%$ light depth was about $30 \mathrm{~m}$ (R. Spinrad, pers. comm.) we assume that phytoplankton production at the depth of the deep protozoan maximum was negligible. Even without the carbon lost during the transfer through the hypothesized microbial loop from bacteria to microheterotrophic flagellates to the larger protozoans, there appears to be insufficient local carbon production to sustain the populations of protozoans observed in these deep maxima.

We used the conversion factor of $2.4 \times 10^{18}$ to go from moles thymidine incorporated to bacterial cells produced (Fuhrman \& Azam 1982); this factor can vary substantially in different water masses and over time (Kirchman et al. 1982). In our case, use of this factor may have led us to underestimate bacterial production somewhat since we estimate bacterial production to be only 2 to $19 \%$ of the primary production $16 \%$ integrated over the top $40 \mathrm{~m}$ ); this is at the low end of the range of values reported from other areas (Ducklow 1983). However, even if we were to have underesti- 
mated the actual production by a factor of 2 , it would still be insignificant in relation to the estimated carbon requirement of the protozoans.

It is possible that the protozoans are relying on an input of organic material from the surface waters for their nutrition. The particle maximum is found in an intermediate water mass which is formed by cooling of surface waters during winter and remains cold throughout the year (Hopkins \& Garfield 1979). Following vernal stratification, biogenic particles produced at the surface which sink below the main pycnocline may accumulate at a hydrographic anomaly such as the current velocity shear or the pcynocline at the base of the cool intermediate water layer. Examination of Lugol's preserved samples with an inverted microscope showed that most of the material in the deep particulate maximum was unidentifiable detritus. The relatively low water temperature (5 to $7^{\circ} \mathrm{C}$ as compared to $>14^{\circ} \mathrm{C}$ in the surface layer) may retard microbial decomposition of this detrital material enough such that the non-living fraction of the detrital particles could represent a significant food source for the protozoans. We also estimated that there were about $3 \times 10^{4}$ intact phytoplankton cells $1^{-1}$ in the deep layer representing a biomass of $1.3 \mathrm{mg} \mathrm{C} \mathrm{m}^{-3}$ (using the conversion in Strathmann 1967); autotrophic microflagellates, which cannot be quantified by using settling chambers and an inverted microscope (Davis \& Sieburth 1982), would add to this biomass of living, but inactive, phytoplankton. This pool of intact cells would need to turn over less than once a day to supply the carbon requirements of the protozoans. Since there is no, or very little, in situ autotrophic production at the depth of the deep protozoan maximum, we need to consider the amount of overlying production that must settle into this layer each day. The integrated primary production on 9 August was $172 \mathrm{mg} \mathrm{C} \mathrm{m}^{-2} \mathrm{~d}^{-1}$. If we consider the deep protozoan layer to have the same thickness as the particulate maximum, $20 \mathrm{~m}$, the average protozoan concentration in that layer is two-thirds the maximum concentration, and the estimated carbon requirement for the protozoans would be $15 \mathrm{mg} \mathrm{C}$ $\mathrm{m}^{-2} \mathrm{~d}^{-1}$; this means that during summer stratified conditions the equivalent of $9 \%$ of the overlying production would need to settle into this layer to sustain the protozoans. There is also the intriguing possibility that the protozoans could be migrating diurnally into the food rich waters above them. Fig. 2 and 3 show that the night-time protozoan distributions have a maximum at about 30 to $40 \mathrm{~m}$. Although our data are limited and such a migration seems prodigious, tintinnids (Capriulo et al. 1982) and Sticholonche (Cachon et al. 1977) can and do swim, and tintinnids, at least, are reported to vertically migrate (Longhurst 1976); thus this hypothesis should be tested.
In summary, we found a deep maximum of $>35 \mu \mathrm{m}$ protozoans which appears to be a wide-spread phenomenon in offshore waters of the Gulf of Maine. These populations appear to be deriving their nutrition from particulates which settle out of surface waters rather than from local phytoplankton or microbial production.

Acknowledgements. We thank Newell Garfield, Jack Laird, Elizabeth Langton, David Phinney and Andy Smith, as well as the captain and crew of the R/V 'Cape Hatteras' for valuable assistance. We also thank Peg Colby and Pat Boisvert for typing the manuscript and Dr. Richard Spinrad for allowing us to publish the transmissometer data in Fig. 3. We thank Dr. Lawrence Mayer for the use of the laser particle counter, and Dr. Bernard McAlice for identifying Sticholonche. This research was funded by National Science Foundation Grant No. EXP 8011448.

\section{LITERATURED CITED}

Azam, F., Fenchel, T., Field, J. G., Gray, J. S., Meyer-Reil, L. A. Thingstad, F. (1983). The ecological role of watercolumn microbes in the sea. Mar. Ecol. Prog. Ser. 10: $257-263$

Beers, J. R., Stewart, G. L. (1967). Micro-zooplankton in the euphotic zone at five locations across the California Current. J. Fish. Res. Bd. Can. 24: 2053-2068

Beers, J. R., Stewart, G. L. (1969). Micro-zooplankton and its abundance relative to the larger zooplankton and other seston components. Mar. Biol. 4: 182-189

Bell, W. H. (1980). Bacterial utilization of algal extracellular products. 1. The kinetic approach. Limnol. Oceanogr. 25 . $1007-1020$

Bell, W. H. (1983). Bacterial utilization of algal extracellular products. 3 . The specificity of algal-bacterial interaction Limnol. Oceanogr 28: 1131-1143

Bell, W. H. \& Sakshaug, E. (1980). Bacterial utilization of algal extracellular products. 2. A kinetic study of natural populations. Limnol. Oceanogr. 25: 1021-1033

Cachon, J., Cachon, M., Tilney, G., Tilney, M. S. (1977). Movement generated by interaction between the dense material at the ends of microtubules and non-actin-containing microfilaments in Sticholonche zanclea. J. Cell Biol. 72: 314-338

Cammen, L. M., Walker, J. A. (1982). Distribution and activity of attached and free-living suspended bacteria in the Bay of Fundy. Can. J. Fish. aquat. Sci. 39: 1655-1663

Capriulo, G. M. (1982). Feeding of field collected tintinnid micro-zooplankton on natural food. Mar. Biol. 71: 73-86

Capriulo, G. M., Carpenter, E. J. (1983). Abundance, species composition and feeding impact of tintinnid micro-zooplankton in central Long Island Sound. Mar. Ecol. Prog. Ser. 10: 277-288

Capriulo, G. M., Gold, K. Okubo, A. (1982). Evolution of the lorica in tintinnids: a possible selective advantage. Annls. Inst. oceanogr., Monaco 58 (Suppl.): 319-324

Caron, D. A., Davis, P. G., Maddin, L. P., Sieburth, J. McN. (1982). Heterotrophic bacteria and bactivorous protozoa in oceanic macroaggregates. Science 218: 795-797

Chrost, R. H., Faust, M. A. (1983). Organic carbon release by phytoplankton: Its composition and utilization by bacterioplankton. J. Plankton Res. 5: 477-493

Davis, P. G., Sieburth, J. McN. (1982). Differentiation of phototrophic and heterotrophic nanoplankton populations 
in marine waters by epifluorescence microscopy. Annls. Inst. oceanogr. Monaco 58 (Suppl.): 249-260

Devol, A. H., Packard, T. T., Holm-Hansen, O. (1976). Respiratory electron transport activity and adenosine triphosphate in the oxygen minimum of the eastern tropical North Pacific. Deep Sea Res. 23: 963-973

Ducklow, H. W. (1983). Production and fate of bacteria in the oceans. Bioscience 33: 494-501

Fenchel, T. (1982). Ecology of heterotrophic microflagellates. IV. Quantitative occurrence and importance as bacterial consumers. Mar. Ecol. Prog. Ser. 9: 35-42

Fuhrman, J. A., Azam, F. (1982). Thymidine incorporation as a measure of heterotrophic bacterioplankton production in marine surface waters: Evaluation and field results. Mar. Biol. 66: 109-120

Fuhrman, J. A., Ammerman, J. W., Azam, F. (1980). Bacterioplankton in the coastal euphotic zone. Distribution, activity and possible relationships with phytoplankton. Mar. Biol. 60: 201-207

Garfield, P. C., Packard, T. T., Friederich, G. E., Codispoti, L. A. (1983). A subsurface particle maximum layer and enhanced microbial activity in the secondary nitrite maximum of the northeastern tropical Pacific Ocean. J. mar. Res. 41: 747-768

Haas, L. W., Webb, K. L. (1979). Nutritional mode of several non-pigmented microflagellates from the York River Estuary, Virginia. J. exp. mar. Biol. Ecol. 39: 125-134

Heinbokel, J. F., Beers, J. R. (1979). Studies on the functional role of tintinnids in the Southern California Bight. III. Grazing impact of natural assemblages. Mar. Biol. 52: 23-32

Hernroth, J. (1983). Marine pelagic rotifers and tintinnids important trophic links in the spring plankton community of the Gullmar Fjord, Sweden, J. Plankton Res. 5: 835-846

Hodson, R. E., Maccubbin, A. E., Pomeroy, L. R. (1981). Dissolved adenosine triphosphate utilization by free living and attached bacterioplankton. Mar. Biol. 64: 43-51

Holm-Hansen, O., Booth, C. R. (1966). The measurement of adenosine triphospate in the ocean and its ecological significance. Limnol. Oceanogr. 11: 510-519

Hopkins, T. S., Garfield, N. (1979). Gulf of Maine intermediate water. J. mar. Res. 37: 103-139

Jannasch, H. W., Pritchard, P. H. (1972). The role of inert particulate matter in the activity of aquatic microorganisms. Memorie Ist. ital. Idrobiol. 29 (Suppl.): 289-308

Jensen, L. M. (1983). Phytoplankton release of extracellular organic carbon, molecular weight composition, and bacterial assimilation. Mar. Ecol. Prog. Ser. 11: 39-48

Karl, D. M., Holm-Hansen, O. (1978). Methodology and measurement of adenylate energy charge ratios in environment samples. Mar Biol. 48: 185-197

King, F. D. (1984) Vertical distribution of zooplankton glutamate dehydrogenase in relation to chlorophyll in the vicinity of Nantucket Shoals. Mar. Biol. 79: 249-256

Kirchman, D., Ducklow, H., Mitchell, R. (1982). Estimates of bacterial growth from changes in uptake rates and biomass. Appl. environ. Microbiol. 44: 1296-1307

Larsson, U., Hagström, A. (1979). Phytoplankton exudate release as an energy source for the growth of pelagic bacteria. Mar. Biol. 52: 199-206

Larsson, U., Hagström, A. (1982). Fractionated phytoplankton primary production, exudate release, and bacterial production in a Baltic eutrophication gradient. Mar. Biol. 67: $57-70$

Linley, E. A. S., Newell, R. C., Lucas, M. I. (1983). Quantita- tive relationships between phytoplankton, bacteria and heterotrophic microflagellates in shelf waters. Mar. Ecol Prog. Ser. 12: 77-89

Longhurst, A. R. (1976). Vertical migration. In: Cushing, D H., Walsh, J. J. (ed.). The ecology of the seas. Blackwell, Philadelphia, p. 116-137

Marshall, K. C. (1979). Growth at interfaces. In: Shilo, M. (ed.) Strategies of Microbial Life in Extreme Environments, Dahlem Konferenzen, Verlag Chemie, Deerfield Beach, Fla., p. $281-290$

Paerl, H. W., Merkel, S. M. (1982). Differential phosphorus assimilation in attached vs. unattached microorganisms. Arch. Hydrobiol. 93: 125-134

Parsons, T. R., LeBrasseur, J. R., Fulton, J. D. (1967). Some observations on the dependence of zooplankton grazing on the cell size and concentration of phytoplankton blooms. J. oceanogr. Soc. Japan 23: 10-17

Pedrós-Alió, C., Brock, T. D. (1983). The importance of attachment to particles for planktonic bacteria. Arch. Hydrobiol. 98: $354-379$

Pomeroy, L. R., Atkinson, L. P., Blanton, J. O., Campbell, W B., Jacobsen, T R., Kerrick, K. H., Woods, A. M. (1983). Microbial distribution and abundance in response to physical and biological processes on the continental shelf of southeastern USA. Continental Shelf Res. 2: 1-20

Pomeroy, L. F., Joharnes, R. E. (1968). Occurrences and respiration of ultraplankton in the upper 500 meters of the ocean. Deep Sea Res. 51: 381-391

Porter, K. G., Feig, Y. S. (1980). The use of DAPI for identifying and counting aquatic microflora. Limnol. Oceanogr. 25: 943-948

Rheinheimer, G. (1981). Investigations on the role of bacteria in the food web of the Western Baltic. Kieler Meeresforsch. (Sonderh.) 5: 284-290

Revelente, N., Gilmartin, M. (1983). Microzooplankton distribution in the Northern Adriatic Sea with emphasis on the relative abundance of ciliated protozoans. Oceanologica Acta 6: 407-415

Shanks, A. L., Trent, J. D. (1979). Marine snow: Microscale nutrient patches. Limnol. Oceanogr. 24: 850-854

Sorokin, J. I (1964). A quantitative study of the microflora in the central Pacific Ocean. J. Cons. perm. int. Explor. Mer 29: $25-40$

Strathmann, R. R. (1967). Estimating the organic carbon content of phytoplankton from cell volume or plasma volume. Limnol. Oceanogr. 12: 411-418

Strickland, J. D. H., Parsons, T R. (1972). A practical handbook of seawater analysis. Bull. Fish. Res. Bd Can. 167. $1-311$

Takahashi, M., Hoskins, K. D. (1978). Winter conditions of marine plankton populations in Saanich Inlet B. C., Canada. II. Micro-zooplankton. J. exp. Mar. Biol. Ecol. 32: $27-37$

Townsend, D. W., Cucci, T. L., Berman, T. (1984). Subsurface chlorophyll maxima and the vertical distributions of zooplankton in the Gulf of Maine. J. Plankton Res. 6: 793-802

Williams, P. J. LeB. (1981). Incorporation of microheterotrophic processes into the classical paradigm of the planktonic food web. Kieler Meeresforsch. (Sondh.) 5: 1-28

Wolter, K. (1982). Bacterial incorporation of organic substances released by natural phytoplankton populations. Mar Ecol. Prog. Ser. 7: 287-295

Yentsch, C. S., Menzel, D. W. (1963). A method for the determination of phytoplankton chlorophyll and phaeophytin by fluorescence. Deep Sea Res. 10: 221-231 